\title{
Slovenian test case Vrbanski Plato aquifer in the EU HORIZON 2020 FREEWAT project
}

\section{Il caso studio dell'acquifero nell'altopiano di Vrbanski (Slovenia) all'interno del progetto EU HORIZON 2020 FREEWAT}

\author{
Irena Kopač, Matev̌̌ Vremec
}

Riassunto: Il caso studio situato in Slovenia, all'interno del progetto EU HORIZON 2020 FREEWAT ha avuto come oggetto l'acquifero dell'altopiano di Vrbanski. In termini di bacini fluviali, la Slovenia è divisa in due distretti: il Danubio e l'Adriatico settentrionale. L'acquifero dell'altopiano di Vrbanski, che presenta una ricarica dal subalveo del fiume Drava sia di tipo naturale che artificiale, fa parte del distretto del bacino del Danubio ed è la fonte di acqua più importante per 14 comuni della parte nordest della Slovenia. Gli Autori hanno studiato l'interazione fra le acque superficiali del fiume Drava e quelle sotterranee dell'acquifero poroso che giace al di sotto dell'antico letto del fiume, assieme alla valutazione di una possibile riduzione dell'impatto ambientale dovuto alla presenza del vicino agglomerato urbano. Questo sito rappresenta in Slovenia la più antica opera di ricarica gestita delle acque sotterranee, utilizzando la tecnica dell'induzione di ricarica da subalveo, e registra ad oggi più di trent'anni di funzionamento efficiente. Rappresenta un impianto piuttosto particolare, caratterizzato da molta abbondanza di risorsa confinata in un piccolo spazio, indipendente dalla siccità e dai cambiamenti climatici, ma vulnerabile a causa dell'impatto della vicina città. Proprio sotto la città è presente uno spartiacque,,che periodicamente si sposta di posizione a causa delle diverse condizioni operative di gestione dell'acqua. Per definire una gestione ottimale della risorsa, gli Autori hanno deciso di utilizzare il plug-

Keywords: Vrbanski Plato aquifer, FREEWAT HORIZON 2020 project, water resource management, artificial groundwater recharge.

Parole chiave: acquifero dell'altopiano di Vrbanski, Progetto HORIZON 2020 FREEWAT, gestione delle risorse idriche, ricarica controllata delle falde.

Irena KOPAČ, 莑节

IEI - Institut for Ecological Engineering

Ljubljanska ul. 9, Maribor, SI-2000, Slovenia

irena.kopac@iei.si

\section{Matev̌̌ VREMEC}

IEI - Institut for Ecological Engineering

Ljubljanska ul. 9, Maribor, SI-2000, Slovenia

matevz.vremec@gmail.com

Ricevuto/Received: 7 August 2017-Accettato/Accepted: 26 September 2017 Pubblicato online/Published online: 30 September 2017

This is an open access article under the CC BY-NC-ND license: http://creativecommons.org/licenses/by-nc-nd/4.0/

(C) Associazione Acque Sotterranee 2017 in FREEWAT incluso nel software QGIS. Con il nuovo plug-in FREEWAT, sviluppato durante l'omonimo progetto, gli Autori hanno sviluppato un modello sia in stato stazionario che in transitorio, per definire lo spostamento dello spartiacque sotterraneo in dipendenza delle diverse condizioni di gestione. Il modello è stato progettato in modo da identificare e descrivere tutti gli aspetti principali del sistema idrogeologico fisico e della gestione idrica. Durante le attività di progetto, è avvenuto un incidente di fuoriuscita di olio di riscaldamento nell'area della città, proprio in corrispondenza dello spartiacque. Pertanto, il modello transitorio (accoppiato ad un modello di trasporto) è stato utilizzato anche per proporre metodologie di riduzione dell'impatto della fuoriuscita di olio, utilizzando una barriera idraulica per implementare una tecnica di pump and treat sul luogo dell'incidente. Lesperienza di applicazione della piattaforma FREEWAT durante il caso studio di Vrbanski è stata molto positiva. La possibilità di gestire i dati direttamente in ambiente GIS, la licenza libera e gratuita, l'organizzazione dei dati in un database relazionale, e gli approcci modellistici inclusi, hanno garantito la funzionalità di uno strumento modellistico adattato ad essere applicato con approccio professionale e a comunicare i risultati del modello agli stakeholder coinvolti. Con l'utilizzo di FREEWAT è stato possibile definire per l'azienda di gestione della risorsa idrica di Maribor le condizioni ottimali per una gestione dell'impianto di approvvigionamento che garantisca il minor impatto ambientale possibile ed un equilibrio fra le portate di pompaggio ed il livello del fiume Drava, questi ultimi particolarmente importanti per l'azienda di gestione dell'energia elettrica della zona. A causa dei vincoli di tempo e di risorse finanziarie, lo studio si è limitato a considerare il periodo compreso fra luglio 2014 e giugno 2017.

Abstract: The Slovenian case study in the EU HORIZON 2020 FREEWAT project was Vrbanski Plato aquifer. Slovenia is divided into two river basin districts: the Damube and the North Adriatic. The Vrbanski Plato aquifer, which he presents both natural and artificial bank filtration from the river Drava, is a part of the Danube river basin district and is the most important water source for 14 municipalities in the northeastern part of Slovenia. We investigated the groundwatersurface water interaction between river Drava and the porous aquifer in the geological old riverbed and possible reduction of city impact. This site is the oldest managed artificial groundwater recharge with riverbank filtration and has more than thirty years of successful operation. It is something special, very abundant in a small space, independent of drought and climate changes, but vulnerable due to the impact of the city. Under the city there is watershed dividing, which is shifting with dif- 
ferent water management condition and we would like to have the least possible impact of the city. For optimal water management we decided to use FREEWAT plug-in within QGIS platform. With new developed FREEWAT plug-in in project FREEWAT, we made steady-state and transient groundwater model for presenting this shift of the watershed dividing under the city and optimal water management for this area. The model was designed in a way that it identifies and describes all major aspects of the physical bydrogeological system and water management. During the running of a project, there was an accident with heating oil spillage in city area, right on the watershed dividing. So we oriented with the transient groundwater model as well on heating oil spillage and pumping with additional wells at the place of the accident to present successful rehabilitation and the importance of the managed groundwater recharge. Our experience with FREEWAT platform during the Vrbanski Plato aquifer case study was very positive. The connection data of the GIS tool, open license and the database monitoring and model approaches functioned as the right tool for a professional approach and communicating with stakeholders. With groundwater models in FREEWAT platform, we defined optimal condition, with as less as possible the impact of groundwater below the city, for pumping water on the Vrbanski Plato, managed by Water Supply Maribor company and needed optimal level in river Drava managed by Drava Power Plants Company. Quantities of pumping for water supply and level of Drava River are the dominant components of water management in this area. Due to the time and financial constraints, we took into account the period from July 2014 to June 2017.

\section{Introduction}

In Slovenia the organized riverbank filtration was first applied in the Maribor water supply system on the Vrbanski Plato aquifer about 50 years ago. The Maribor water supply system provides water to this region (about $600 \mathrm{~km}^{2}$ and with about 200.000 residents). With $1300 \mathrm{~km}$ of water supply pipes, 37 wells, and 73 water reservoirs, this is the largest system of water supply in Slovenia. The Vrbanski
Plato aquifer (Fig. 1) represents the most important water resource in this system and has a total capacity of $760 \mathrm{l} / \mathrm{s}$. The pumping station of Vrbanski Plato is able to meet the whole water needs of this region, but for now, it covers up to $70 \%$, depending on the functioning of other pumping stations and other water resources. Some of them are more climate dependant as Vrbanski Plato and in drought periods, we need more water from the Vrbanski Plato. In 2015, for example, the Vrbanski Plato pumping station comprised $60 \%$ of the Maribor drinking water supply. (Kopač et al. 2017).

The use of bank filtrated waters of the Drava River did not begin in an intensive way. The wells were drilled into the aquifer of a geologically abandoned riverbed at a distance of about $800 \mathrm{~m}$ upstream and $1200 \mathrm{~m}$ downstream of the river banks. By pumping the wells, the bank infiltration was induced from both the upstream and downstream banks of the river. More intensive bank filtration began in year 1978 with construction of wells on the island situated in the middle of the Drava River. There were many prejudices against the use of bank filtrated river water because of distrust about its quality. At that time, the Drava River was more burdened by the wood-processing industry in Austria. However, due to the series of hydroelectric plants in Austria and Slovenia, there was always a lot of self-cleaning ability in the river. We never had any problem with quality of bank filtrated water. Years ago, Austria closed this industry and the quality of the Drava River has improved even further.

This filtrate is now applied as an artificial recharge of the mentioned aquifer to augment the existing $400 \mathrm{l} / \mathrm{s}$ capacity of the aquifer and to some extent also to protect the drinking groundwater against the endangering pollution from the city. Four wells on the island were constructed, each with $75 \mathrm{l} / \mathrm{s}$, together having $300 \mathrm{l} / \mathrm{s}$ capacity. This bank water is then infiltrated via negative wells at a $250 \mathrm{~m}$ distance from the drinking water wells. The negative wells should have been first constructed on the other site of the pumping wells, opposite

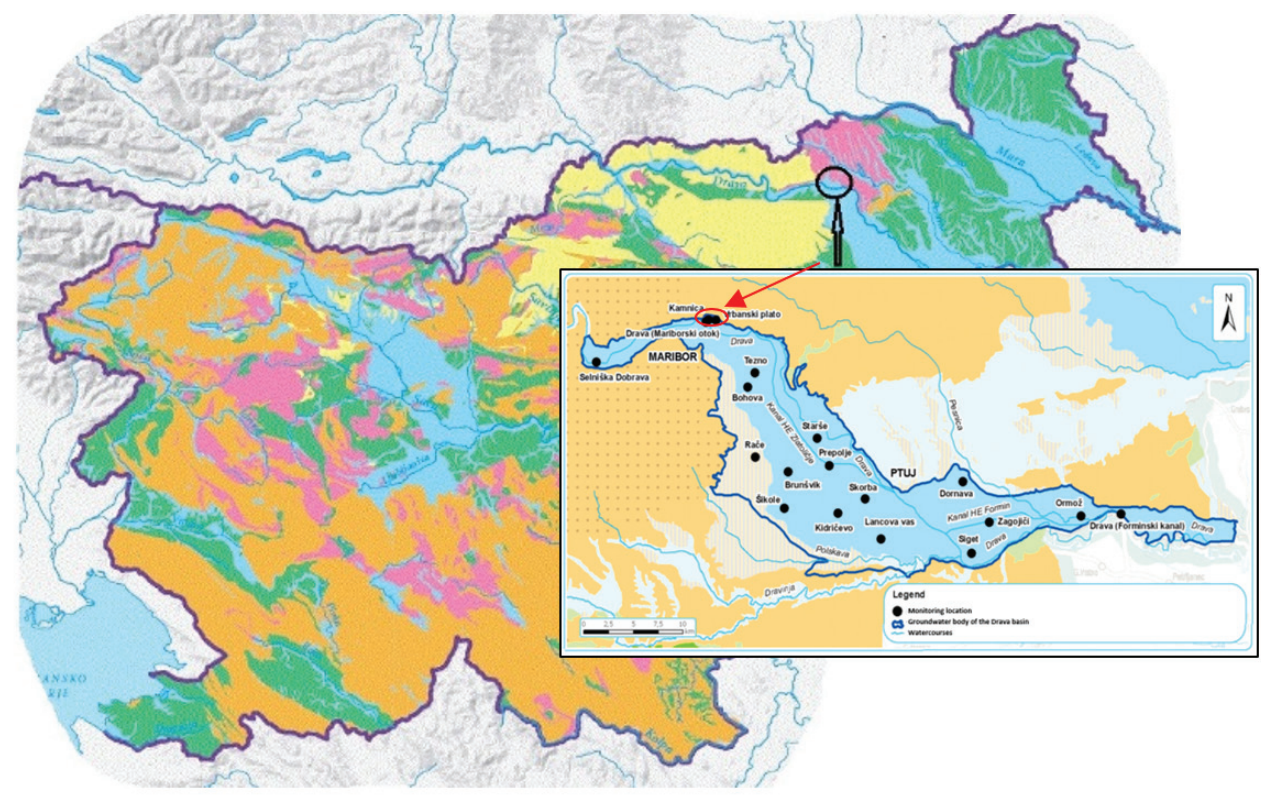

Fig. 1 - Location of the Vrbanski Plato aquifer (Kopač et al. 2017).

Fig. 1 - Localizzazione dell'acquifero nell'altopiano di Vrbanski (Kopač et al. 2017). 
to the city. However, at that time this was not possible, due to insurmountable reasons (Rismal and Kopač 2000). Now the whole system is foreseen, including the missing negative wells opposite to the city. In these 50 years of the operation of bank filtration without and with groundwater recharge, two groundwater contaminations occurred on the city side; the first was with $\mathrm{Cr}+6$ and the second with Trihalomethanes. In both cases, the artificial recharge was very useful for rapid recovery of the system (Rismal and Kopač 2000).

Since the end of 1986, with the first phase of the artificial groundwater recharge fully carried out, until 1992, detailed control measurements were conducted, which ensured the integrity of Maribor Island and protected the groundwater quality. Later, the monitoring focused primarily on the quality and the level of the groundwater. Based on these observations several groundwater models of the Vrbanski Plato were made. These models have been following trends in their field, but they never got enough attention from stakeholders or water management. The area of the Vrbanski plato aquifer is protected by the national Decree on water protection zone of the water body of Ruše, Vrbanski plato, Limbuška Dobrava in Dravsko polje (Official Gazette of RS, No. 24/2007). The regulation was established based on the national Rules of designation of water protection area (Official Gazette of RS, Nos. 64/04, 5/06, 58/11 and 15/16). The regulation determines the water protection zones and water protection regime for the area. Internal areas are indicated on the lower publication map marked as followed (Figure 2):

- $\quad$ areas of intake marked in white, labelled with »VVO $0 \ll$;

- inner protection zone marked in orange, labelled with $»$ VVO I $\ll$;

- $\quad$ middle protection zones marked in yellow, labelled with $» \mathrm{VVO} \mathrm{II} \ll$;

- $\quad$ outer protection zones marked in green, labelled with »VVO III $\ll$.
Participation in the FREEWAT project has given us a new opportunity to show the importance of groundwater modelling in Induced RiverBank Filtration (IRBF) as a widely used technique in the Managed Aquifer Recharge (MAR). The project results in an open source and public domain for a GIS integrated modelling environment model for simulating water quantity and quality in both surface and groundwater with an integrated water management and planning module (Rossetto et al. 2015).

Our case study has two main objectives. One was testing the newly developed FREEWAT platform in QGIS environment and the other was our wish to obtain high-quality groundwater flow model and view on certain key scenarios for better water management. The conducted study investigated the groundwater-surface water interaction between the Drava River and the porous aquifer in the old geological riverbed of the Drava River. The reason for the case study derives from a desire for good understanding of aquifer: the Drava relation and the impact of artificial groundwater recharging, which is induced riverbank filtration. In the time of the project duration in March 2016, a large quantity of heating oil was spilled in the inner city of Maribor. A leak was detected in a supply pipe between a heating oil tank and the boiler room of the municipality building. Due the fact that the spill site was in a water-protected area, immediate intervention and remediation measures had to be carried out. The first steps included the historical research of the spillage, an on-site inspection with water sampling at the nearest existing observations wells, laboratory analysis of soil from new boreholes and the excavation of the upper layer of contaminated soil. The excavation was limited by the stability of the municipality building and the $25 \mathrm{~m}$ thick unsaturated zone. By analysing the sequence of events, we found that, over a short period, approximately $20 \mathrm{~m}^{3}$ of heating oil was spilled partly reaching the aquifer and forming a floating oil lens (Fig. 3).

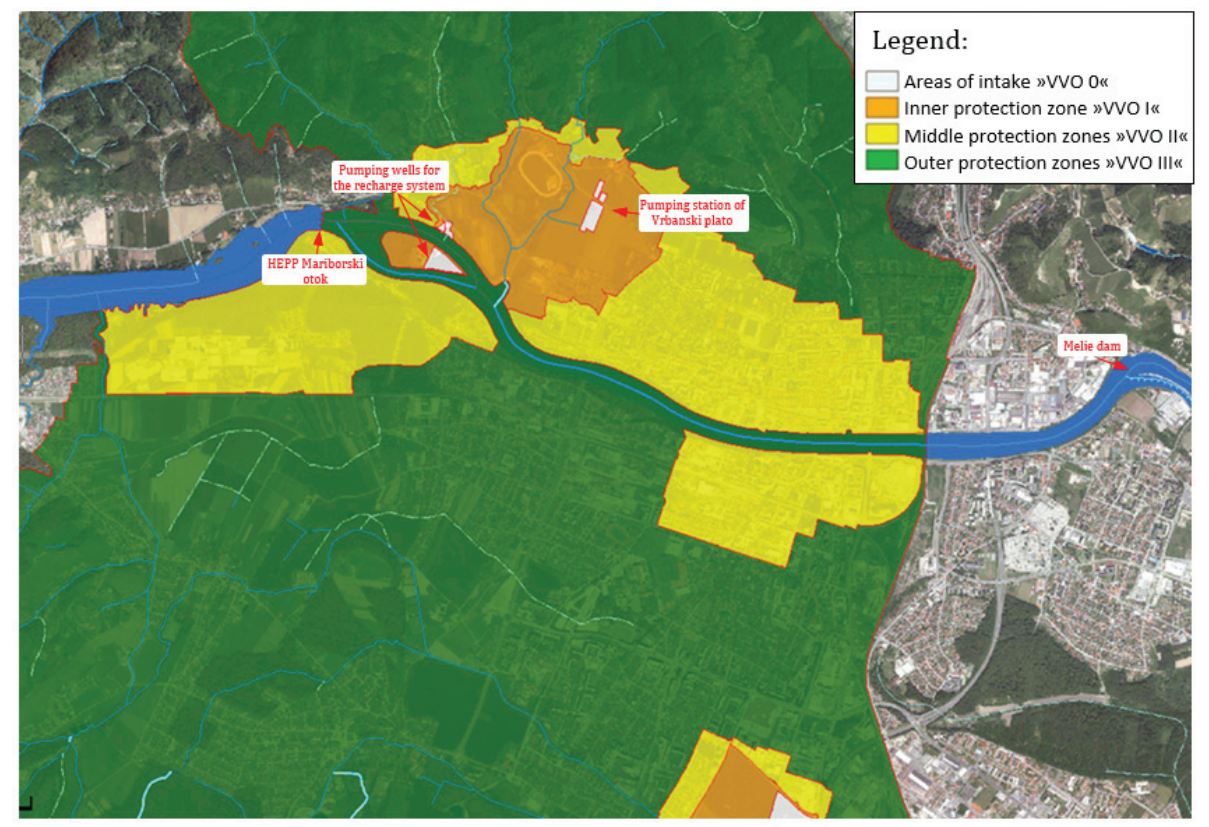

Fig. 2 - Water protection zones in the area of the aquifer Vrbanski plato (source base: ARSO Slovenia).

Fig. 2 - Zone di protezione idrogeologica dell'acquifero nell'altopiano di Vrbanski (fonte: ARSO Slovenia). 


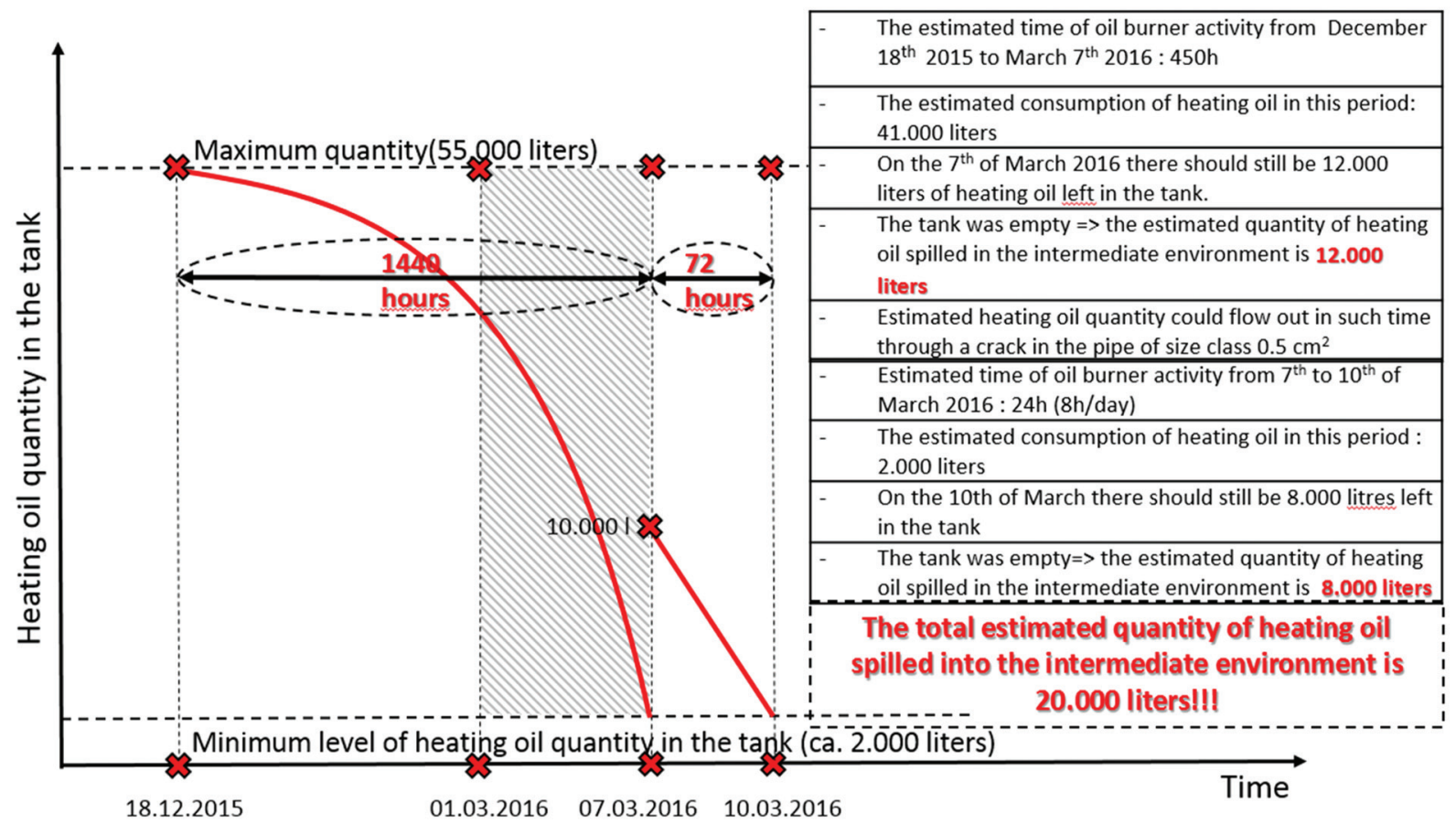

Fig. 3 - Reconstruction of heating oil spillage event (Blažeka et al. 2016).

Fig. 3 - Ricostruzione dell'evento di fuoriuscita dell'olio di riscaldamento (Blažeka et al. 2016).

\section{Description of the groundwater aquifer}

The first major pumping station on the aquifer of the Vrbanski Plato was built between 1956 -1959, when the municipality had to build an experimental pumping station due to a lack of a drinking water supply. Before the construction of the dam in Melje and the hydroelectric power plant in Zlatoličje (southeast from Maribor), the predicted usage capacity of drinking water was estimated to be around $100 \mathrm{l} / \mathrm{s}$. Because of the dam construction in Melje, the level of Drava River rose and increased the yield of the aquifer so now it is possible to pump up to $460 \mathrm{l} / \mathrm{s}$ without specific measures and $760 \mathrm{l} / \mathrm{s}$ with the first step of MAR (Kopač 2008).

Figure 4 shows the groundwater flow in the area of the Vrbanski Plato. The plane area on the left and right Drava riverbank between Maribor Island and Melje is composed of gravel and sand quaternary alluvium. Deposition of gravel and sand followed an era of intense lifting, in which Drava cut its deep riverbed under the foothills of hills. The riverbed then was $14 \mathrm{~m}$ deeper than it is today at Maribor island. Now in the western part of the Limbuška Dobrava, the Drava infiltrates into the aquifer's groundwater body above the HEPP Maribor Island, which is then merged with the hinterland waters flowing from the Pohorje hill. The groundwater direction is then in the direction of Maribor Island in the middle of Drava River, where the river additionally infiltrates the groundwater. In the area of Maribor Island, there are also pumping wells for the first step of the artificial groundwater recharge system. The groundwater then flows to the pumping station of the Vrbanski Plato. From the other side of the city, the groundwater flow is a consequence of the groundwater depression, which is created by the drawdown in the pumping station. The flow from the direction of the city centre is recharged by the Drava, which infiltrates in the Lent area (part of the city).

In the city centre, a groundwater divide occurs, as a part of the groundwater flows to the pumping station and the other detours towards the industrial part of the city known as Melje. When the dam was built, the level of the Drava was a little higher as the terrain elevation. For this reason, an impermeable barrier was constructed with drainage for draining the groundwater below the Melje dam into the Drava River. Between Maribor Island and the pumping station, the Vrbanski Plato in the Vinarje Valley is the location of infiltration wells for artificial recharge of groundwater (Kopač, 2008).

\section{Implementation of groundwater flow model}

On the Vrbanski Plato aquifer we have a lot of monitoring data, mostly from water supply company Mariborski vodovod (within his water safety plan, build on HACCP system) and MUVOON - Inter-municipalities Agency for environmental protection and nature conservation Maribor, which already for 15 years carries out yearly immission monitoring on groundwater, soil and surface water, which influences groundwater. QGIS/FREEWAT platform (FREEWAT, 2017) could be an efficient tool to manage these data and use them for groundwater modelling, for sustainable water resource management and research scenarios for the next steps of artificial groundwater recharge.

We decided for one model layer with unconsolidated gravel and sand and also with silt on the riverbank and for the next 


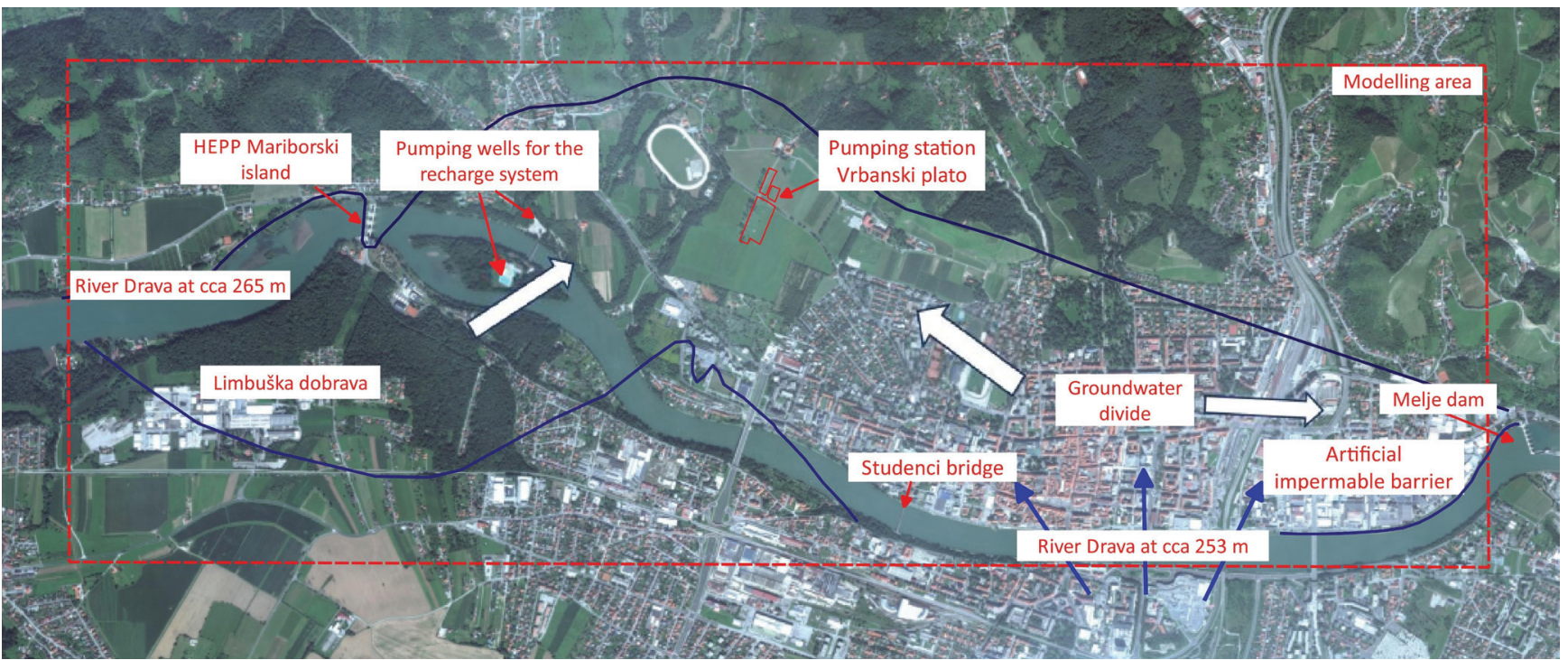

Fig. 4 - Conceptual model of Vrbanski Plato aquifer (Blažeka et al. 2016).

Fig. 4 - Modello conettuale dell'acquifero nell'altopiano di Vrbanski (Blažeka et al. 2016).

models of water management scenarios (Kopač and Vremec 2017):

1. steady-state model with 50 x $50 \mathrm{~m}$ grid cell size and with average monitoring data for the year 2015; here, we made a base model and studied three additional scenarios:

b. average pumping in the wells $(396 \mathrm{l} / \mathrm{s}$ ) and active artificial groundwater recharge $(165 \mathrm{l} / \mathrm{s}$ ) (base model simulation with calibration and validation);

c. average pumping in the wells (396 l/s) without artificial groundwater recharge;

d. maximum pumping (636 1/s in year 2015) in the wells and active artificial groundwater recharge (191 l/s in year 2015);

e. maximum pumping (636 1/s in year 2015) in the wells without artificial groundwater recharge;

2. steady-state model with $5 \times 5 \mathrm{~m}$ grid cell size and with average monitoring data for the year 2015;
3. transient model with 5 × $5 \mathrm{~m}$ grid cell size (Fig. 5) for a period between July 2014 to June 2017, including a large quantity of heating oil, that has been spilled in March 2016 in the inner city of Maribor and two newly constructed pumping well for reducing the contamination of the heating oil in October 2016.

The model area is located between the following two extreme points in the modulated Gauss-Krüger, coordinates:

$$
\begin{array}{ll}
\mathrm{X}_{\min }: 545325 \mathrm{~m} & \mathrm{X}_{\max }: 551725 \mathrm{~m} \\
\mathrm{Y}_{\min }: 157000 \mathrm{~m} & \mathrm{Y}_{\max }: 159225 \mathrm{~m}
\end{array}
$$

The investigated domain is $2250 \mathrm{~m}$ large and $6400 \mathrm{~m}$ long.

The bottom surface (Figure 6) of the model layer was determined based on a raster file representing the impermeable layer. The raster file of the impermeable layer was created with the interpolation of drill holes data of the impermeable layer across the area.

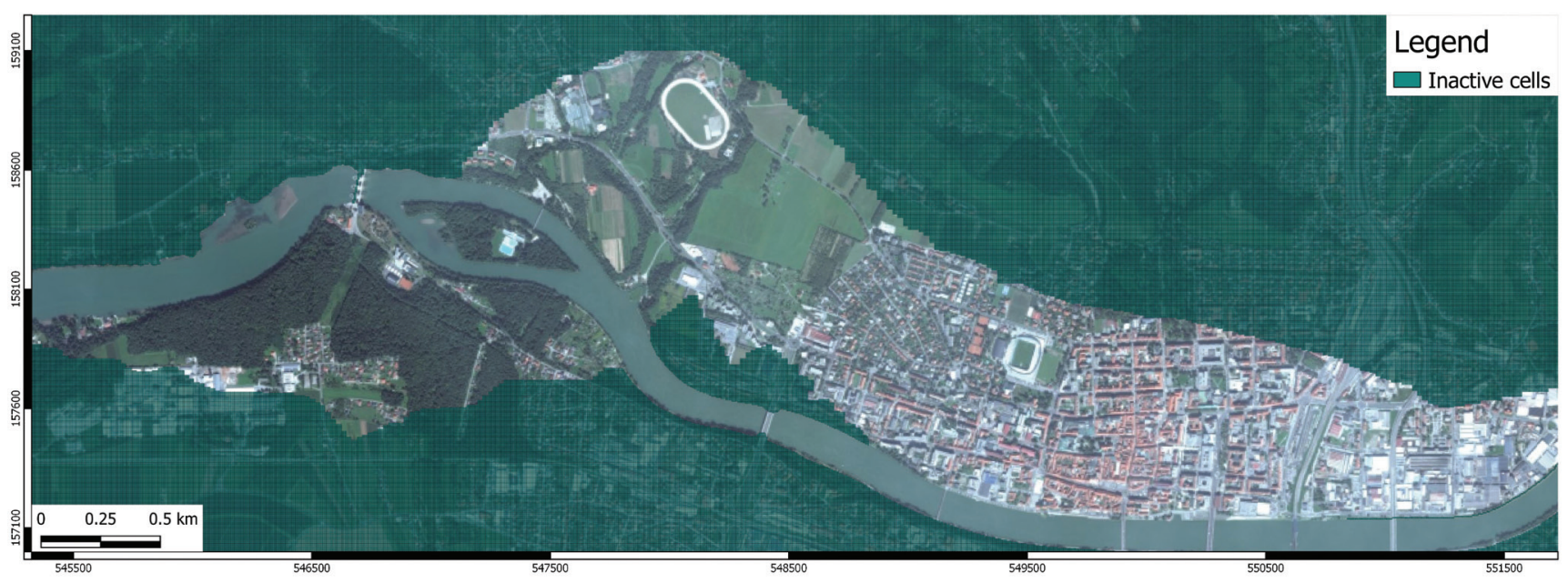

Fig. 5 - Active domain used in the $5 \times 5$ transient model (Kopač and Vremec 2017).

Fig. 5 - Dominio attivo utilizzato nel modello transitorio 5 x 5 m (Kopač and Vremec 2017). 


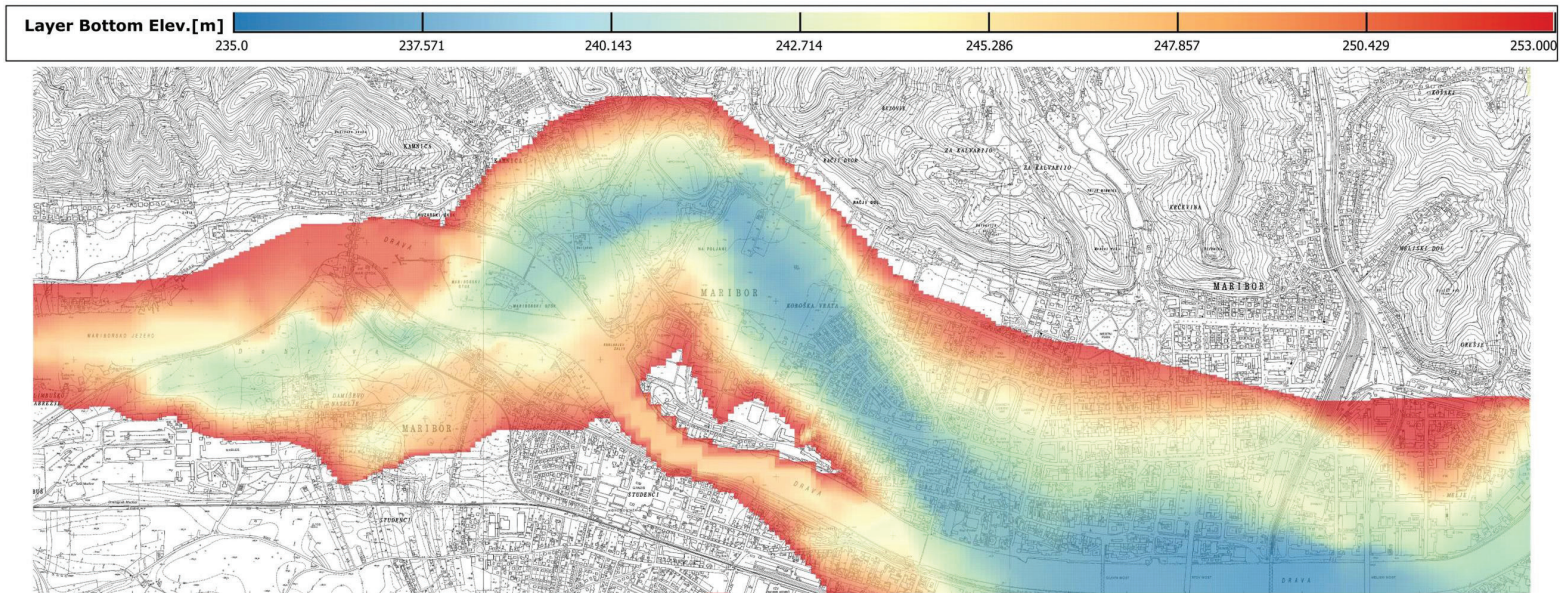

Fig. 6 - Contour table and height of the impermeable layer (Kopač and Vremec 2017).

Fig. 6 - Carta della quota del letto dello strato impermeabile (Kopač and Vremec 2017).

The top surface (Figure 7) was determined with values of a digital elevation model. Values of the raster files mentioned above were attributed using the FREEWAT tool "copy from Raster layer".

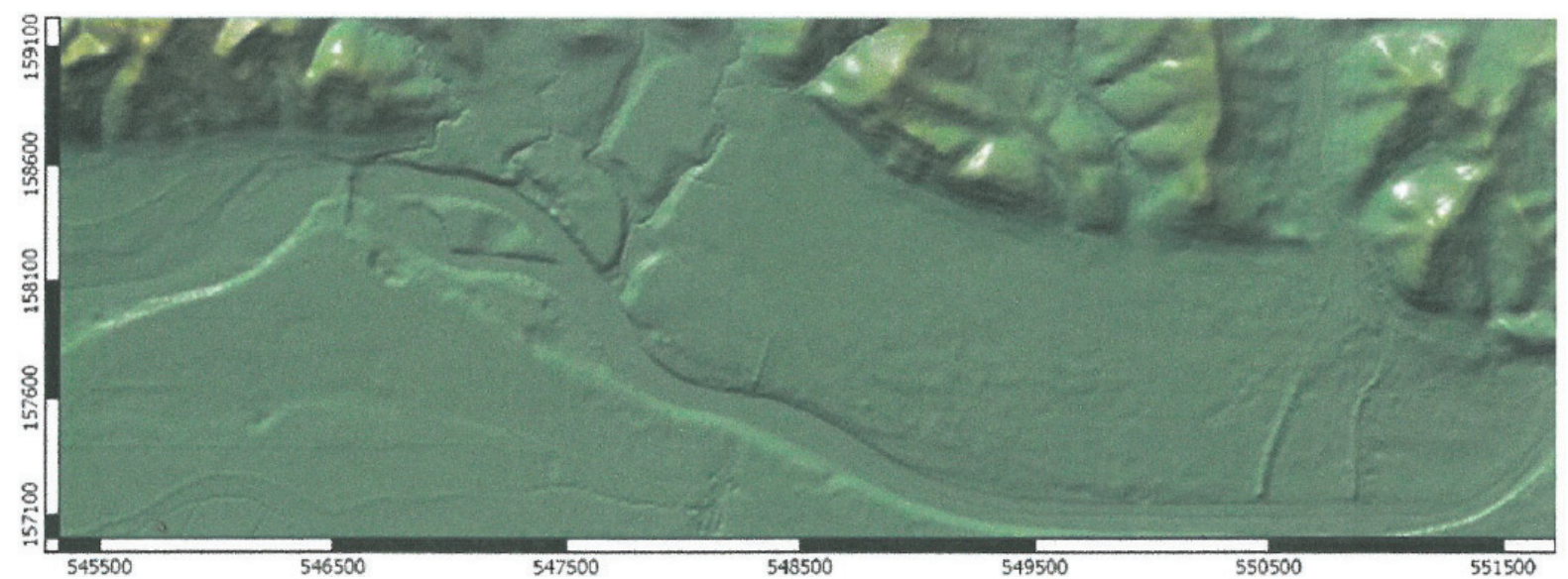

Fig. 7 - Digital elevation model of the domain (Kopač and Vremec 2017).

Fig. 7 - Modello di elevazione digitale del dominio (Kopač and Vremec 2017).

With QGIS we defined model thickness and the thickness of the unsaturated zones. The model thickness (Figure 8) stretches from $0,1 \mathrm{~m}$ on the borders to 25 meters.

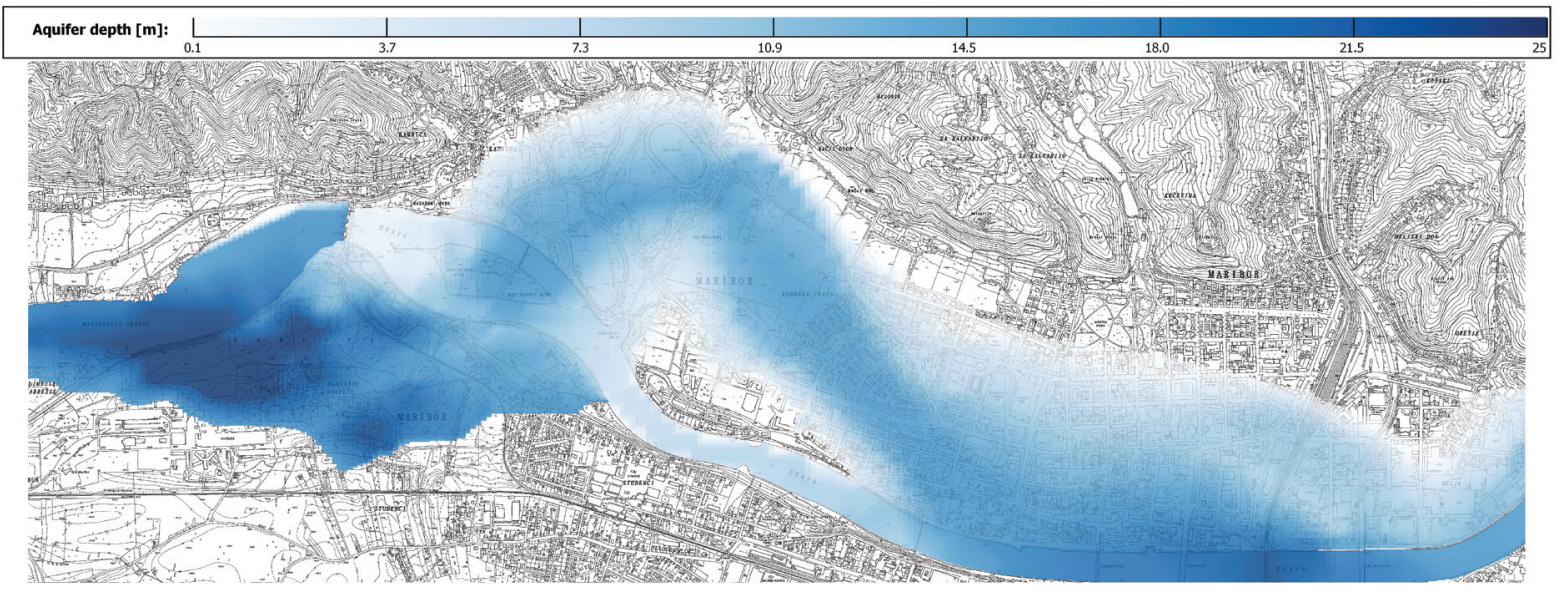

Fig. 8 - Contour table of the model layer thickness (Kopač and Vremec 2017).

Fig. 8 - Carta delle isopache del modello (Kopač and Vremec 2017). 
The thickness of the unsaturated zones (Figure 9) stretches from 0,1 m to 40 meters on the north borders under the hills.

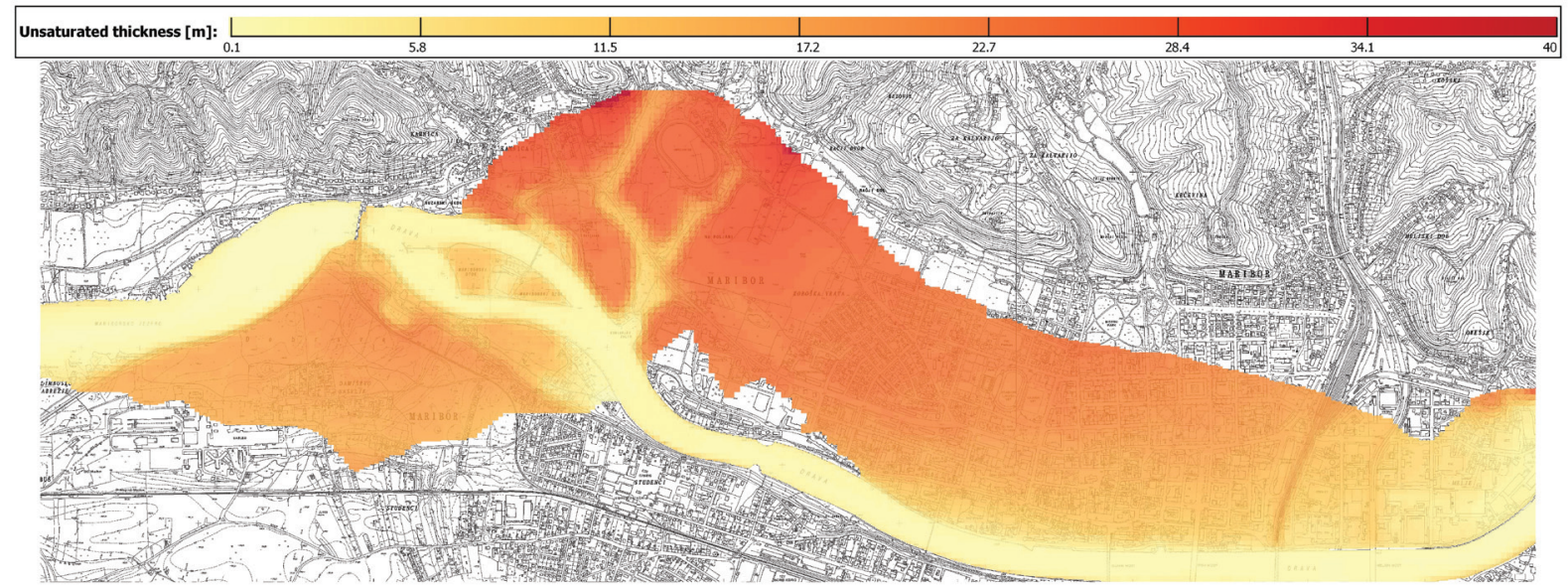

Fig. 9 - Contour table of the unsaturated layer thickness (Kopač and Vremec 2017).

Fig. 9 - Carta dello spessore dello strato insaturo (Kopač and Vremec 2017).

The geometrical and hydrogeological characteristics of the aquifer were determined based on pre-made reports (Kopač 2008) and research in this area. The research carried out estimated the hydraulic conductivity of the aquifer range between 1.10-3 $\mathrm{m} / \mathrm{s}$ and $8.10-3 \mathrm{~m} / \mathrm{s}$ (Figure 10). The hydraulic conductivity is lower in the area of the riverbed, due to soil settling, which is sealing areas of the riverbed and contributing to a lower hydraulic conductivity comparing to the rest of the aquifer. Regarding the previous research, we divided the grid into different hydraulic coefficient zones (polygon and line shapefiles), which were later calibrated using the UCODE module (Figure 11).

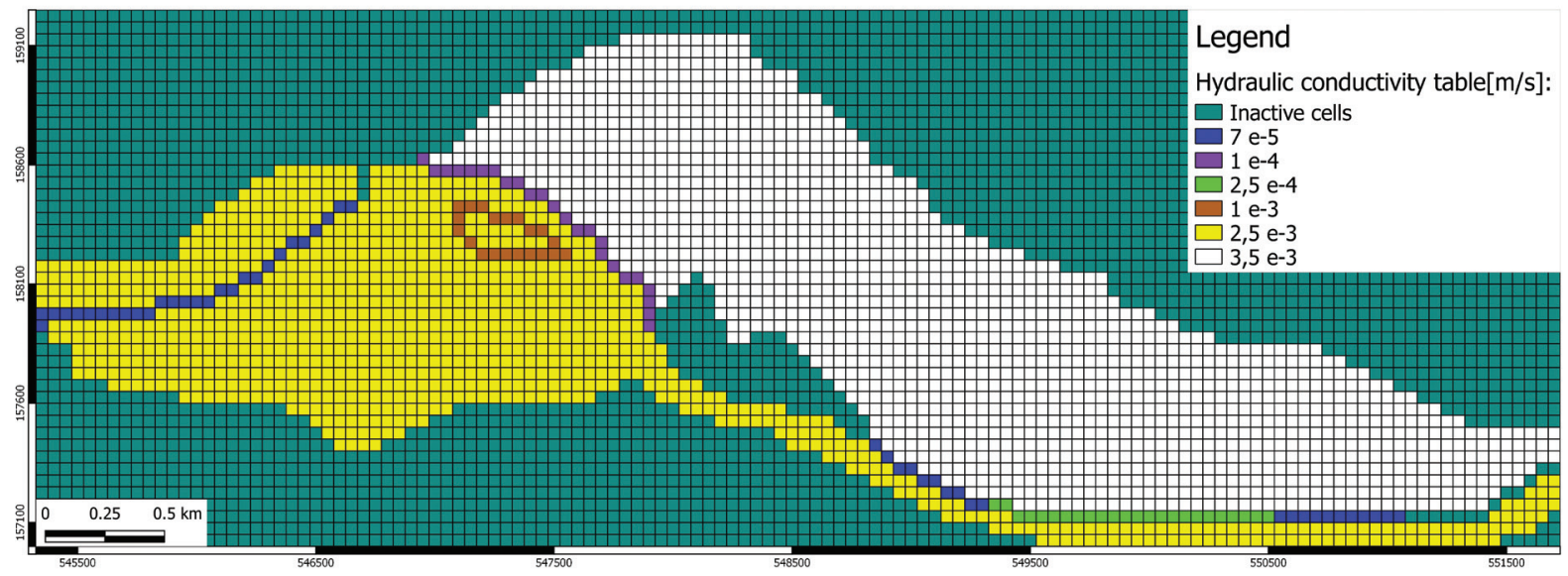

Fig. 10 - Location of zones with different hydraulic conductivity values (Kopač and Vremec 2017).

Fig. 10 - Localizzazione delle zone caratterizzate da valori diversi di conducibilità idraulica s (Kopač and Vremec 2017).

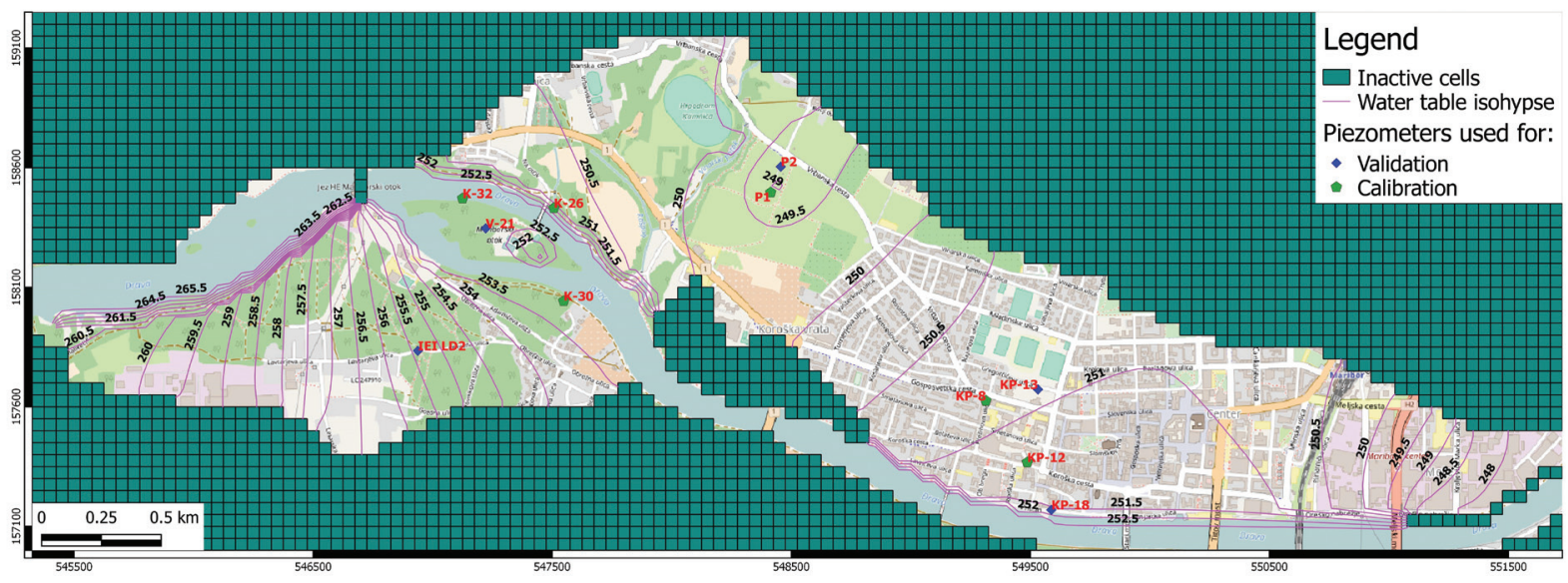

Fig. 11 - Simulated groundwater head with the location of piezometers used for calibration (Kopač and Vremec 2017).

Fig. 11 - Quota piezometrica simulata con l'ubicazione dei piezometri utilizzati per la calibrazione (Kopač and Vremec 2017). 
The groundwater hydrology of our model area is extremely diverse, which allowed us to test different packages for boundary conditions. For the model area, the following boundary conditions were taken into account:

- the RIVER package - infiltration of the Drava (around $400 \mathrm{l} / \mathrm{s}$ as average) infiltration of groundwater from right side in Drava River (around $5 \mathrm{l} / \mathrm{s}$ ): the geometry of the river bottom was determined based on measurements of the cross sections of the river regular made by Drava Power Plants Company;

- the RECHARGE package - surface precipitation (around $35 \mathrm{l} / \mathrm{s}$ as average) of two zones (city area and green area),

- the CHD package - hinterland groundwater flow from the Pohorje mountains (around $25 \mathrm{l} / \mathrm{s}$ as average);

- $\quad$ the WELL package: pumping from 4 pumping wells on Maribor Island and 14 pumping wells (around $400 \mathrm{l} / \mathrm{s}$ as average) in the area of the Vrbanski Plato pumping station, 2 pumping wells in area of heating oil pollution (as $20 \mathrm{l} / \mathrm{s}$ as average), and 2 artificial groundwater recharge wells in the area of the Vinarje brook (around $165 \mathrm{l} / \mathrm{s}$ as average);

- the DRN - the draining of groundwater in Melje (35 1/s as average).

As we have already written, in March 2016 a large quantity of heating oil was spilled in the inner city of Maribor. For the localization of the oil plume and recovery measures nine new boreholes were drilled. Groundwater sampling showed that the contamination did not spread to a larger area. Based on an extended analysis, a measure with implementation of two remediation wells for a floating oil layer recovery system by dual pump-and-skim technology (Delin and Herkelrath 2014) was applied for the prevention of the spreading and long-term attenuation of the contamination. The dual pumpand-skim technology was composed of two pumps inside each remediation well with a large groundwater pump for the formation of a cone of depression and a small skimmer pump for the temporary pumping of the floating oil layer. The water is pumped into an oil separator and a storage tank that is regularly cleansed (Blažeka et al. 2016).
So on the 19th October 2016 two pumping wells started to operate in the area of the municipality, for reducing the contamination from the heating oil spillage that happened in this area. The simulations performed with the transient model are meant to indicate the effects of the newly constructed wells on the aquifer water table and the location of the watershed divide. The stress periods were therefore divided into several groups. The first indicating the time, before the construction of the wells, and the others indicate different times of equal pumping quantities at the newly constructed wells. This time discretization goes from July 2014 to June 2017.

\section{Results}

The results of the use of FREEWAT platform in QGIS environment consist of a database entry groundwater monitoring, key hydrogeological maps and land use maps of the area, producing models of groundwater flow and pollution transport and display of key results and data model. All this is within a single project in a QGIS environment. Groundwater models include a steady-state, transient and transport models with two grid cell sizes ( $50 \times 50 \mathrm{~m}$ and $5 \times 5 \mathrm{~m}$ ).

Because of heating oil spillage the most important result for our local authorities and stakeholders involved in water resource management was to present a proper water management with a model to ensure that the polluted area will not spread to the catchment area of the Vrbanski Plato pumping station. Of course, we also got a clear picture of the flow of the groundwater in this area and the operation of induced riverbank filtration (IRBF) as part of our managed aquifer recharge schemes (MAR).

For first estimation of water management and the flow path of the oil, we conducted the next scenarios (Figures 12 and 13) with different pumping and recharge values for the groundwater recharge system:

1. Scenario: predicted average pumping quantities of pumping wells at the pumping station Vrbanski Plato (396 1/s in year 2015), with the water recharge system values set to zero.

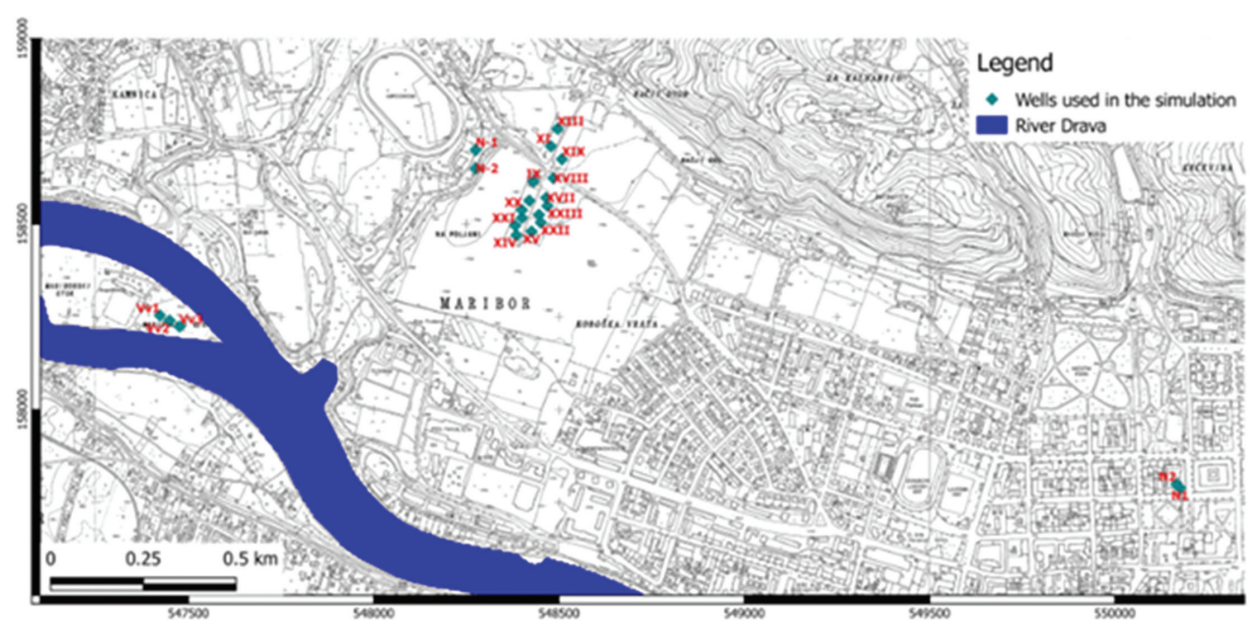

Fig. 12 - Water protection zones in the area of the aquifer Vrbanski plato (source base: ARSO Slovenia). (Kopač and Vremec 2017).

Fig. 12 - Zone di protezione idrogeologica nell'area dell'acquifero nell'altopiano di $\mathrm{Vr}$ banski (fonte: ARSO Slovenia). (Kopač and Vremec 2017). 
2. Scenario: predicted maximum pumping quantities of pumping wells at the pumping station Vrbanski Plato (636 l/s in year 2015) with the water recharge system set to maximum value (191 l/s in year 2015).

3. Scenario: predicted maximum pumping quantities of pumping wells at the pumping station Vrbanski Plato (636 l/s in year 2015), with the water recharge system values set to zero.

While conducting the scenarios, the location of the watershed dividing in the town center was observed. This location is crucial for the quality of the groundwater pumped at Vrbanski Plato and the direction of the spillage showed in the Figure 13 with the sign:

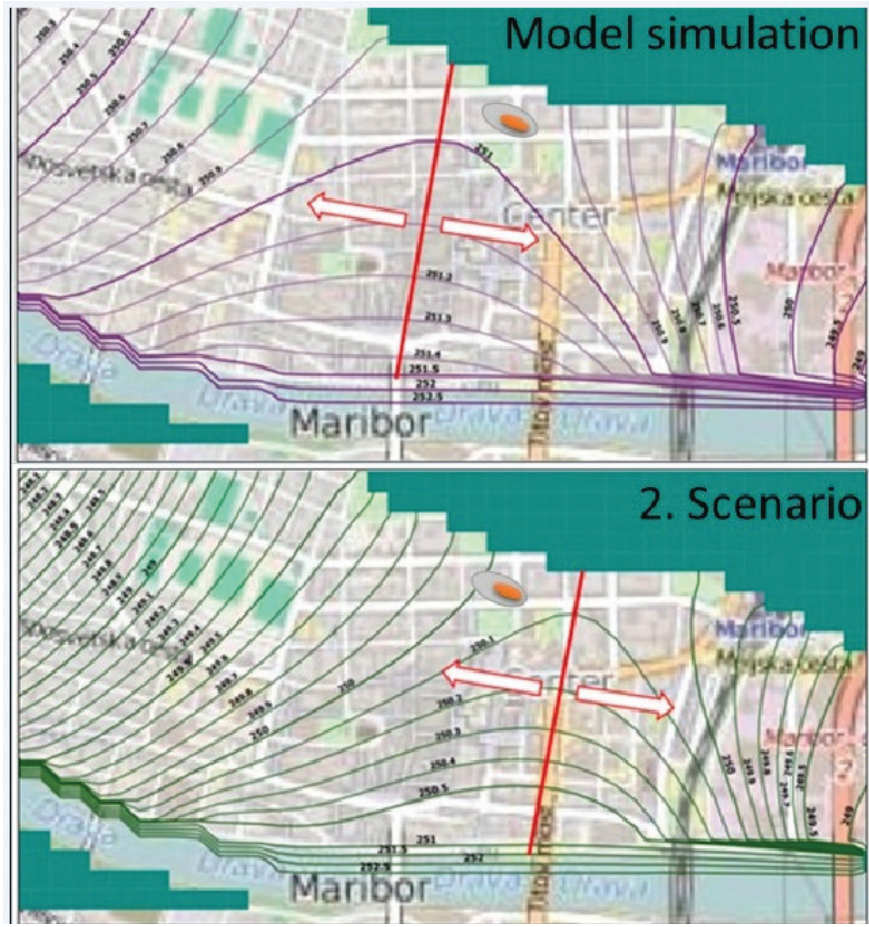

next steps of remediation we constructed a detailed transient and transport model with $5 \times 5 \mathrm{~m}$ grid cell size. These all were really helpful for testing the usefulness of tool QGIS/ FREEWAT and to confirm successful engineering measures in the area of fuel oil spillage.

\section{Discussion}

The Vrbanski Plato case study is investigating the groundwater surface water interaction between river Drava and the porous aquifer in the geological old riverbed of river Drava and how to reduce the impact of the city. The reason for the case study derives from the desire scientifically based understanding of the aquifer - river Drava relation, the impact

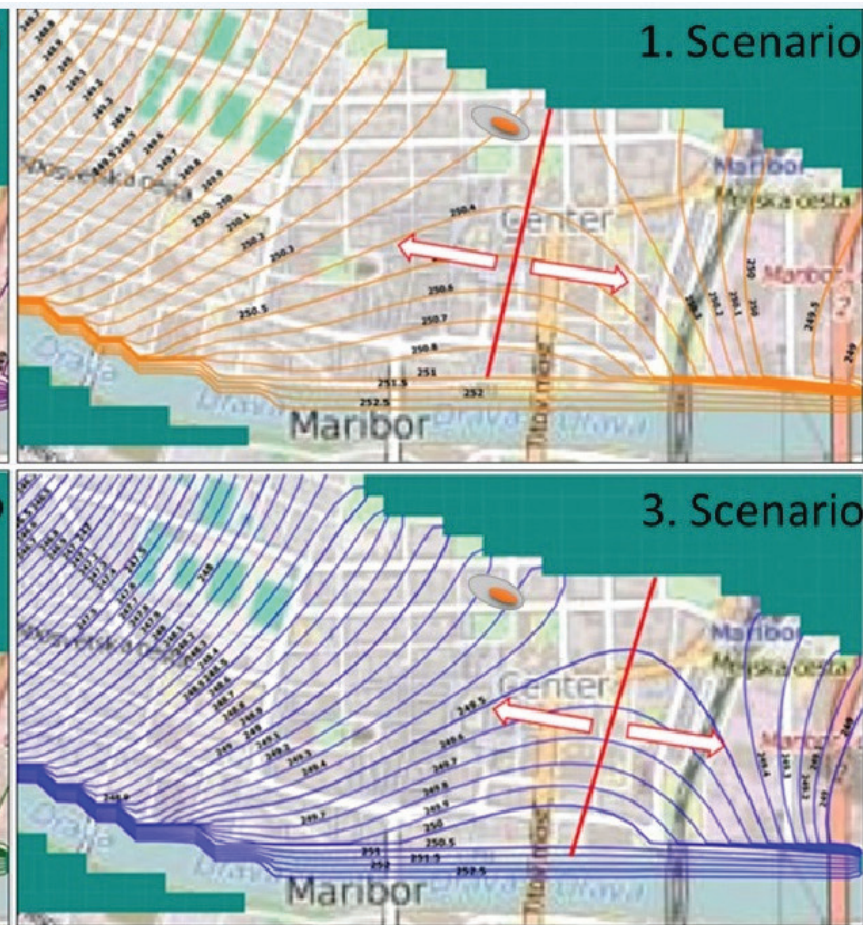

Fig. 13 - The location of divide in different scenarios of water management in the catchment of Vrbanski plato pumping station and the direction of the spillage (Kopač and Vremec 2017).

Fig. 13 - Posizione dello spartiacque secondo diversi scenari di gestione dell'acqua nel bacino della stazione di pompaggio nell'altopiano di Vrbanski e direzione della fuoriuscita dell'olio (Kopač and Vremec 2017).

The model simulation with an average pumping station and with active water recharge systems indicated that the spill extends towards the drain in Melje and was not threatening the quality of the drinking water pumped at Vrbanski Plato. All of the other scenarios (maximum pumping at the Vrbanski Plato or no artificial groundwater recharge) simulated the shift of the watershed divide towards Melje, consequently redirecting the oil spillage and more polluted water towards the pumping station of Vrbanski Plato instead of directing the contaminated water towards the drainage in Melje.

One year after the spill approximately one half of the spilled oil has been recovered. With the setup of the recovery system and the remediation wells, the contaminant was stabilized in a depression created in the water-table (Figures 14 and 15). The full remediation and attenuation of the spillage will be a slow process, which will take years to recover from. To support of artificial groundwater recharging along with the river bank infiltration, and to determine how and where the divided groundwater under the city flows to the pumping wells and in the opposite direction. This was particularly important by the spill of heating oil in the area where the groundwater flow divides under the city.

With tool QGIS/FREEWAT as platform to create GIS data and groundwater numerical model, we were able to analyze groundwater flow under various conditions of bank filtration from river Drava and artificial groundwater recharging. For further development of the exploitation of the Vrbanski Plato aquifer, it is very important to know the influences of:

- water management (drinking water supply, hydroelectric power stations),

- the first step of artificial groundwater recharge and a planned second step, 


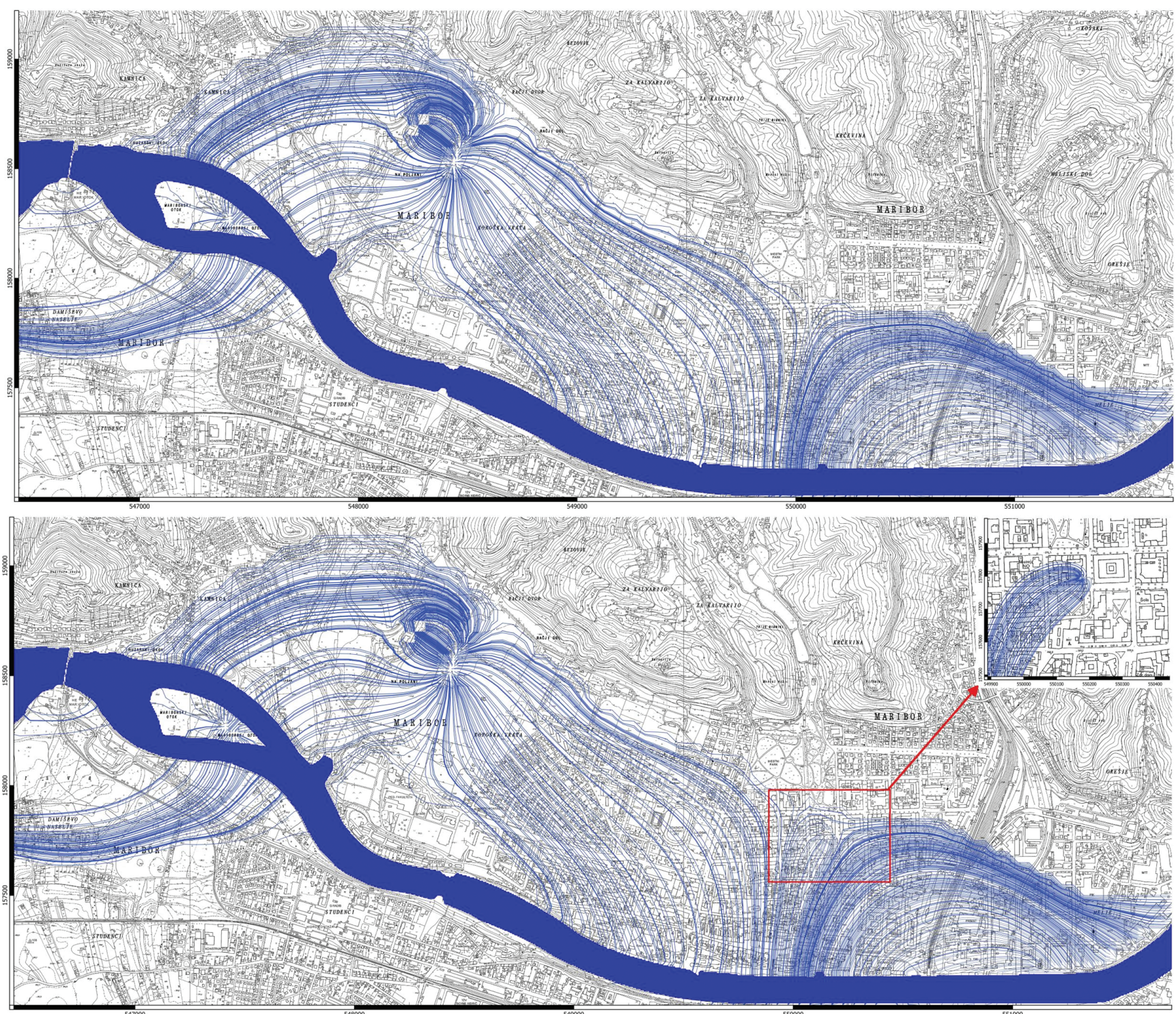

Fig. 14 - MODPATH particle tracking before the construction of the remediation wells (upper picture/sp1) and after the construction of the remediation wells (lower picture/stress period (sp) 11).

Fig. 14 - Tracciamento delle particelle mediante MODPATH prima della costruzione dei pozzi di bonifica (immagine superiore / sp1) e dopo la costruzione dei pozzi di bonifica (immagine inferiore/ periodo di stress (sp) 11).

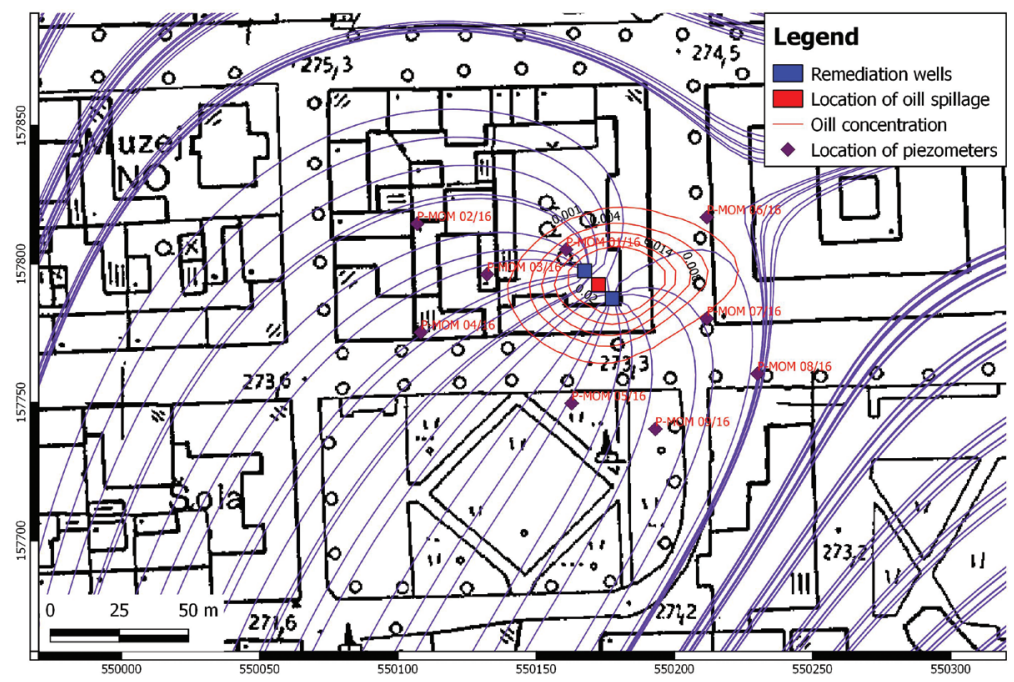

Fig. 15 - Location of heating oil spillage with two remediation wells with groundwater flow and oil concentration (maximum pumping / sp4, November/December 2016).

Fig. 15 - Ubicazione della fuoriuscita dell'olio di riscaldamento con due pozzi di bonifica insieme al flusso di acqua sotterranea e alla concentrazione dell'olio (max pompaggio / sp4, novembre / dicembre 2016). 
- the groundwater pollution problem (particularly from the Maribor city center) and solute transport.

The results clearly illustrated the key information - changing the distribution of underground water flow under the city and the necessary elements for proper management of this water source, which should be taken into account by water supply company and operator of hydroelectric power stations.

With this tool, we could also have more intensive involvement of key stakeholders, involved in the management of this water resource and its impact. For the future work, the basis of GIS information and the groundwater flow model is a very good starting point for analyzing additional scenarios in this area, updating the model and monitoring data.

\section{Conclusion}

The Vrbanski Plato aquifer is the most important water resource for 14 municipalities in the northeastern part of Slovenia. Here we have a very good conditions for induced riverbank filtration (IRBF) as part of our managed aquifer recharge schemes (MAR). In spite of the fact that the system is not yet at its final planned shape, the results are satisfactory, but only under certain restrictions.

In the FREEWAT project, we had two main objectives. One was testing the newly developed FREEWAT platform and its usefulness. The connection data of the GIS tool, open license, and the database for monitoring and model approaches functioned as the right tool for a professional approach, communication and exchanging ideas with stakeholders as well as for the presentation of results allowing for good visualization tools (Kopač and al. 2017). As a partner in the FREEWAT project with case study Vrbanski Plato, we have a very positive experience. This tool feels right for us and we will continue to work with it. Through creating a common environment among water research / professionals, policy makers and implementers, FREEWAT's main impact will be most felt in enhancing science and in the participatory approach and evidence-based decision making in water resource management, hence, producing relevant and appropriate outcomes for policy implementation (Rosseto et al. 2015).

Another important goal was to obtain high-quality model of groundwater and view on certain key scenarios for better water management. The results show that by this first step of IRBF with MAR we can control pollution by the city to some extent and that we have increased the capacity of whole system. When the system works in good hydrological conditions of the Drava River (the level at an altitude of $253.00 \mathrm{~m}$ ) and the average pumping amounts for water supply (around $400 \mathrm{l} / \mathrm{s}$ ) and the artificial groundwater recharge in the amount of about $165 \mathrm{l} / \mathrm{s}$, we have less water polluted by city and stable water quality. When the system work in less favorable hydrological conditions of the Drava River or/ and in large quantities of pumping amounts (around $650 \mathrm{l} / \mathrm{s}$ ) and with the artificial groundwater recharge in the amount of about $200 \mathrm{l} / \mathrm{s}$, the proportion of polluted water from the city is higher. The quality of water in the pumping station is little worse but still meets the regulations on the quality of drinking water. However, in the case of an accident with a fuel oil spill in city center, we would have drawn it in the direction towards the pumping station.

For the more efficient operation of the entire system, proper management of this water source is required. On one side, this should be based on the provision of regular hydrological and quality monitoring at the key points of the aquifer and on the other side, it is important to have proper tool as expert system for support.

Acknowledgment: This paper is presented within the framework of the FREEWAT project, which has received funding from the European Union's Horizon 2020 research and innovation programme under Grant Agreement n. 642224

\section{REFERENCES}

Blažeka Ž, Kopač I, Rajh B, Kračun M, Levačić I, Krajnc A, Kopač T (2016) The emergency intervention and rehabilitation works due to spillage of fuel oil in the building of the Municipality of Maribor. Proj. No. 6T-16138, IEI - Institute for Ecological Engineering Ltd., Maribor, Slovenia

Delin G, Herkelrath W (2014) Effects of a Dual-Pump Crude-Oil Recovery System, Bermidji, Minnesota, USA. Groundwater Monitoring and Remediation 34, Winter 2014, p. 57-67 ured. s.l.s.n.

FREEWAT, http://www.freewat.eu/. Last accessed on: $3^{\text {rd }}$ July 2017.

Kopač I (2008) Hydrogeological model of Vrbanski Plato - Action programme for further step for artificial recharge on Vrbanski Plato; Proj. No. 6V-7H2.1, IEI - Institute for Ecological Engineering Ltd. Maribor, Slovenia

Kopač I, Vremec M, (2017) FREEWAT - FREE and open source software tools for WATer resource management, Appendix 4, Report on the application of FREEWAT to Vrbanski Plato case study (Slovenia), Version 0.3, July 2017

Kopač I, Vremec M, Kračun M (2017) A groundwater artificial recharge management tool: Case study of the Drava River in Maribor, River Basin Management 2017, $9^{\text {th }}$ International Conference on River Basin management, $19^{\text {th }}-21^{\text {st }}$ July 2017, Prague, Czech Republic, Wessex Institute of Technology

Rismal M, Kopač I (2000), Riverbank filtration as pre-treatment of river water for artificial recharge of groundwater for drinking water supply of the city Maribor - Workshop: Attenuation of Groundwater Pollution by Bank Filtration, $15^{\text {th }}-17^{\text {th }}$ June 2000, Dresden, Germany

Rossetto R, Borsi I, Foglia L (2015) FREEWAT: FREE and open source software tools for WATer resource management, Rendiconti Online Società Geologica Italiana, 2015, 35, pp. 252-255

Rossetto R, Foglia L, Borsi I, Kopač I (2015) FREEWAT - open source integrated modelling environment (surface- and groundwater). Proceedings of the $6^{\text {th }}$ Croatian international Water Conference - Croatian water on investment wave; R.4.07., pp. 1327-1334; $20^{\text {th }}-23^{\text {rd }}$ May 2015, Opatija, Croatia 